\title{
JÁN HORECKÝ‘S APPROACH TO LANGUAGE AND THINKING
}

\author{
MIROSLAV ZUMRÍK \\ L’udovít Štúr Institute of Linguistics, Slovak Academy of Sciences, Bratislava, \\ Slovakia
}

\begin{abstract}
ZUMRÍK, Miroslav: Ján Horecký‘s Approach to Language and Thinking. Journal of Linguistics, 2017, Vol. 68, No 2, pp. $426-431$.

Abstract: The paper aims to reflect on theoretical foundations of Horecky's approach to the relation between language (and more specifically: terms) and thinking (concepts). Reflections are devoted to Horeckýs explicit and implicit beliefs on the nature of terms and concepts and their mutual relation, as well as their relation to reality around. Definitions of both term and concept appear in some of Horecký's major papers. The paper focuses on models of term-concept relation proposed in those papers. Finally, an attempt is made to find some convergences and divergences in theories of Horecký and the Czech logician Pavel Tichý.
\end{abstract}

Keywords: terms, concepts, philosophy, Ján Horecký, Pavel Tichý, logical spectrum, Transparent Intensional Logic

\section{LANGUAGE AND THINKING}

In his book Spoločnost' a jazyk (Society and Language), Horecký writes: "The outer reality is always reflected in the natural language in some way, that is, it is designated by linguistic means. The relation of objective reality, thinking and language is often represented by the so called semantic triangle" [3, p. 16].

This is basically an Aristotelian view in the sense that objective reality, thinking and language exist as three separate domains. These three nevertheless interact with each other, which means that the questions of philosophy are not restricted to the limits of either categories of mind (as for Kant) or those of language (as for Wittgenstein). The outer reality is, as Horecký states, always reflected in the natural language in some way. This leaves, on the one hand, room for further interpretation, as long as the way of this reasoning is left without further specification. On the other hand, Horecký clearly suggests that the relation between outer reality and natural language is that of a reflection. At the same time, Horecký admits that this reflection can be labeled as designation. He introduces classic semantic triangle consisting of the object/thing (reality), the name of the thing (language), and the concept, generalization of the thing (thinking). The relation of the name of the thing and the thing itself is, contrary to name-concept, and concept-thing relations, "immediate only during communication, that is, in cases where a given name is used to directly naming a certain thing" $[3, \mathrm{p} .17]$. In other cases, the relation between a name (language) and the thing (object, reality) is mediated through several levels (logical, semantic, onomasiological). It is this complex and dynamic form of mediation between the language, thinking and the world around where, as I would argue, 
Horecky's theory proves inspirational for further discussion on the nature of concept/ term relation. In this way, the paper continues in the line of the research that seeks to uncover inspirations stemming from Horeckýs linguistic and terminological achievements, such as in [5].

Horecký states that it is not only a string of characters/sounds that constitute a sign which would then stand for a given object [3]. The sign can only fulfill its function when it is linked to a given concept of the object. This means that it is both the domain of language and the domain of thinking that "stand for" the domain of reality: the sign is not unilateral, but bilateral. A sign has two aspects, one of them being the chain of sounds and the other being the concept. Let us see closer now at the way how the domains of thinking and language "stand for" the reality.

Though Horecký assumes that the "objective" reality is somehow reflected in our thinking and the language, his understanding is more subtle. However, Horecký's belief in reality existing independently on language remains intact. He distances himself from the view of L. Weisberger who claims that language actually forms certain categories independently of the objective reality [3, p. 24]. For Horecký, language is an instrument of thinking. The language, contrary to the extreme form of linguistic relativism, does not determine human thinking. As an example, Horecký mentions the cultures of Hungary and Slovakia that have much in common despite quite different features of the Hungarian and Slovak language.

"The relation between a name and its object in extralingual reality is not that simple as represented in semantic triangle. Not even the concept "concept" is fully unproblematic 1197040685 " [3, p. 18]. The reality for him is not just plainly reflected - projected - into thinking and language, but these three domains are rather intertwined in a dynamic and, as Horecký puts it, dialectic way. The dialectical relation (mutual dependency) of the domains is possible thanks to their structural features, that enable interaction, overlapping and correspondence between elements of the domains (objects, concepts and names/terms): "relation between concept and term is built on the very nature of concept - that its content consists of a set of features - and on the very quality of language - that it can express at least one of these features thanks to expressive means of language" [1, p. 101]. These structural features Horecký explores in another paper [4], where he describes system of "conceptualizers", grammatical and semantic categories that enable expressing structure of reality in the structure of language.

As already mentioned, Horecký stresses that the relation between the name and the named object is rather layered, and that even concept of a concept is not selfexplaining. Here, it is possible to mention current discussions on the ontological status and further features of concepts as entities, and draw a possible parallel between these discussions and peculiarities of Horecký's approach. Amongst many participants in the discussions, I would like to name inspiring work of P. Tichý, creator of the logical system called Transparent Intensional Logic [6]. Tichý claims, that names (or terms) refer not directly to objects of reality, but rather to specific abstract entities - procedures that construct these objects [7, p. 131]. Concepts in TIL are defined as a special type of these constructions. Some hints of procedural and constructionist understanding of concepts can be found even in Horecký's 
approach. Horecký believes that we use concepts in order to describe and process reality. When describing an unknown object of reality, we actually describe various features of this object, we assign these features to the object and thus construct an open set of logical predicates, the logical spectrum [3, p. 18], which is a term introduced by Watanabe [10]. As an example, Horecký uses the term parketáren̆ (parquetry factory), and its logical spectrum: (1) it is a certain place or facility (this we know thanks to the suffix -áreñ), (2) where something is produced (again, this we know because of the suffix), (3) production of this something is in some way organized (because of the suffix) and (4) this something is parquetry (this we know from the root of the word, parket-, stemming from "parquetry"). Since logical predicates result from mental activities, they are not objective in the way logicians like P. Tichý assign concepts and cognitions their objective existence.

We have seen that Horecký presupposes existence of certain linguistic features that enable expressing logical predicates in language. These linguistic means of expressing logical predicates he calls semantic features. To every logical predicate, there exists a semantic feature in the domain of language. In case of the term parketáreň (parquetry factory), he names semantic features contained therein as miestovost' (placeness), výrobnost' (produceness), organizovanost' (organizedness) and predmetnost' (objectness) [3, p. 19].

The set of logical predicates is open and the predicates can be added, removed or replaced due to changes in the actual state of (scientific) knowledge. For a given concept, there can exist several logical spectra, depending on philosophical standing point of a researcher, state-of-the-art within a given field etc. Horecký thus adheres to a "dynamic concept of a concept" that goes beyond the somehow "static" definition of a concept, defined as a generalized reflection of those aspects of a given object that are essential for human knowledge [2, p. 130]. The logical spectrum is also defined as a set of propositions that do not contradict each other, while each one expresses some feature of a given concept (ibid.). This opens for a dynamic understanding of concepts, whose content undergoes changes in the course of time. Therefore, these are in no way "eternal" Platonic objects, but cognitive constructions and instruments that enable us to think and speak of the outer, common reality.

According to Horecký, not every semantic feature expressing the logical predicates from the set of logical spectrum has to be expressed in the term itself [3, p. 19]. There is, however, always possible to discern two elementary parts, onomasiological base and onomasiological specification (priznak). In the example term "parquetry factory", there is semantic feature of "placeness" expressed in the onomasiological base and the name of the produced object expressed in the onomasiological specification. Which features of the onomasiological base will appear in the name of an object is decided at the onomatological level. This distinction leads to, as Horecký puts it, rather complicated scheme of realitylanguage relation. The scheme consists of six levels with corresponding entities (level of reality - objects, logical level - logical predicates, semantic level-semantic features, onomasiological level - morphemes/words, onomatological level derivational morphemes/words and phonological level - morphemes, phonemes. The first three levels are separated from remaining three, which means that the 
thinking and objective being are not directly part of a language sign. However, language and thinking are, in Horecký's opinion, both distinct and tightly interconnected and can be described as complex dialectic unity, which then needs to be examined from multiple perspectives [3, p. 20]. Horecký introduces a system of four domains that together build an opposition to the domain of reality. These four domains are: language as a system of signs $(j a z y k, \mathrm{~J})$, language as usage of the system of signs (reč, R), thinking (myslenie, $\mathrm{M}$ ) as reflection of reality based on sensory perception, and as psychic activity of a subject. Finally, there is an exclusive domain of human thinking, the logical thinking (L), consisting of logical operations and information processing. Horecký organizes these four domains as vertices of a square, where there is direct and mutual dependence between vertices on the same side ( $M$ with $J$ and with $\mathrm{L}$, $\mathrm{J}$ with $\mathrm{M}$ and with $\mathrm{R}, \mathrm{R}$ with $\mathrm{J}$ and with $\mathrm{L}, \mathrm{L}$ with $\mathrm{M}$ and with $R$ ), but not across the square. This means that there is no direct connection between thinking $(M)$ and language as usage of the system of signs $(R)$, nor between language as sign system (J) and logical thinking/logical operations (L). This square scheme applies to the so called cognitive thinking (poznávacie myslenie), while there is also a communicative thinking (komunikativne myslenie), whose function is to process knowledge into information, which, consequently, can be transmitted to others [3, p. 22].

\section{TERMS AND CONCEPTS}

Recurring definitions of term and concept can be found throughout Horeckýs bibliography. Apart from his seminal monograph Foundations of Slovak terminology (1956), one could mention Horeckýss papers published in various scholarly journals like Kultúra slova, Jazykovedný časopis, Slovenské odborné názvoslovie or Naša reč.

The term belongs to the domain of language, whereas concept is an entity within the domain of thinking. Horecký's definition of term originates from terminological practice and takes into account the relation of term and concept: term is a name of a concept that is delimited by the concept's definition and by its position within conceptual system of a given scientific field [2, p. 130]. In an earlier version of this definition, a term is the name of a concept within a given scientific field or production area. Every term only has meaning and fulfills its function within the conceptual system of a given scientific field [1, pp. 98-99]. Concept is defined as a cognitive summary of individual objects (be it material or immaterial) on the basis of their common features. [1, p. 99].

The relation of onomatological structure of a term and the logical spectrum of a concept is not univocal: not every feature from the logical spectrum finds its expression in the structure of a term (ibid.). Normally, only the most significant (prominent) feature (differentia specifica) of a given concept is expressed through the structure of the term, while the other features are present implicitly, in the location of a concept/term within other concepts/terms of a given field. Which feature will be present in the structure of a term depends on existing or possible models for creating terms in a given language. The variety of such models is not unlimited, it is a "closed system" [1, p. 100]. 
At the same time, the relation of onomatological structure and the logical spectrum of a concept is, as Horecký puts it, "dialectical" (mutually dependent). Logical spectrum changes faster than the onomatological structure of a term, because the spectrum reflects progress in scientific knowledge [2, p. 131]. Finally, this relation is mediated, with the onomasiological and semantic structure added between the former two levels. Onomasiological structure of a term consists of the base and specification, semantic structure consists of "meaning constructions" created by human mind (ibid.).

The most prominent feature in the logical spectrum of a concept becomes the main "motivational feature", expressed in the form of a term [1, p. 100]. The motivational feature can either express inherent features of objects in question, or their relational features, which follow from the objects' relation to other objects. In each language, there are some general models of how these features are used for coining terms. In Slovak, Horecký distinguishes two models of creating terms using inherent features: one model he calls "adjective" (adjektivny), the second one "verbal" (slovesny). Other models are based on relational features. Some of these models express general relation of a feature to the entity in question, other express relations of location, purpose, material, time or similarity.

\section{HORECKÝ AND TICHÝ}

Finally, as hinted in Section 1, I will turn to the question whether there can be traced some similarities or differences between Horeckýss and P. Tichý's approach to meaning and reference. In his paper What do we talk about? [8] Tichý distinguishes extensional and intensional entities and focuses on their reference. If it is true that intensional entities (propositions, individuals-in-intension, qualities, relations etc.) can be defined as functions that yield values (extensional entities like truth values, individuals, numbers or sets of individuals), do intensions exclusively refer to extensional entities? Tichý advocates quite the opposite, that by mentioning intensional entities, we actually refer to intensional entities themselves [8, p. 39]. Horecký would probably agree with Tichý, given that for Horecký, the terms are names of concepts as abstract entities (like intensions), not names of real objects (like extensions). However, Horecký adopts the view that concepts are mental generalizations located in individual and social consciousness [1], whereas Tichý believes they have an objective, albeit abstract existence, which we can and we do refer to, when we speak. Logicians like P. Tichý or H. Putnam think of terms like "planet", "crow" etc. like of functions and qualities ("to be a planet", "to be a crow"), not like of sets of individuals [8, p. 42]. Horecký believes concepts are generalizations, in other words, mental representations of sets of individuals. It is possible that Horecký would agree with Tichý, who claimed that by using terms like "planet" or "crow", we do not refer to individuals or sets thereof, but instead we refer to a certain quality understood as a function or a role named "being a planet" or "being a crow". In another paper [9], Tichý explains that the sentence "Mary's husband is dead" is not about Mary's real husband, but about the role of being person in certain relation to Mary, in other words, about the role of being husband of Mary, whoever this 
person might be. "Mary's husband" is, then, not a name of a real person, but a name of a certain function, called individual role. It is obvious that such claim might sound rather counterintuitive. Where Tichý builds semantics of natural language using a logical calculus, Horecký adheres to rather Aristotelian metaphysics, albeit with faceted model of relation between reality, language and thinking.

I would like to conclude that despite differences in their philosophical standpoints, as well as substantial geographical distance between Horecký and Tichý (who exiled to New Zealand in 1970), there are some similarities in their approaches. Even without Tichý's refined logical system with rich procedural semantics, Horecký throughout his life reflected upon the complexities and dynamics of reality-language relation. Both Horecký and Tichý, then, were reluctant to clear-cut and simplistic models of how and with what reference we use natural language.

\section{ACKNOWLEDGEMENTS}

This article was written within the VEGA project $\mathrm{n}^{\circ}$ 2/0114/15 Analysis of terminology work of Ján Horecký as an inspiration for the terminology management of the 21st century in Slovakia implemented at the Slovak National Corpus Department.

\section{References}

[1] Horecký, J. (1960). Vzt’ah pojmu a termínu. Jazykovedný časopis, 11(2):97-102.

[2] Horecký, J. (1974). Základné problémy terminológie. Kultúra slova, 8(5):129-132.

[3] Horecký, J. (1982). Spoločnost' a jazyk. Veda, Bratislava.

[4] Horecký, J. (1987). Systém konceptualizátorov. Slovenská reč, 52(4):207-214.

[5] Šimková, M., editor (2015). Človek a jeho jazyk. 3. Inšpirácie profesora Jána Horeckého. Veda, Bratislava.

[6] Tichý, P. (1988). The Foundations of Frege's Logic. De Gruyter, Berlin and New York.

[7] Tichý, P. (1996a). Konstrukce. In O čem mluvíme? Vybrané stati k logice a sémantice, pages 119146, Filosofia, Praha.

[8] Tichý, P. (1996b). O čem mluvíme? In O čem mluvíme? Vybrané stati k logice a sémantice, pages 37-58, Filosofia, Praha.

[9] Tichý, P. (1996c). De dicto a de re. In O čem mluvíme? Vybrané stati k logice a sémantice, pages 79-94, Filosofia, Praha.

[10] Watanabe, S. (1969). Knowing and guessing - a quantitative study of inference and information. John Wiley \& Sons, New York. 